KuLTura- MeDia-TeoLogia

ISSN 2081-8971

$2017 \mathrm{nr} 30$, s. 30-51.

\title{
Jak zwiększyć skuteczność organizacji non profit korzystając z social media? Case study na podstawie wybranych fundacji katolickich
}

How to increase the effectiveness of non-profit organizations using social media? Case study based on selected Catholic foundations

\begin{abstract}
ABSTRAKT:
NA PRZYKEADZIE WYBRANYCH ORGANIZACJI POŻYTKU PUBLICZNEGO (KATOLICKICH I ŚWIECKICH) POKAZUJE,

JAK WYKORZYSTAĆ MEDIA SPOŁECZNOŚCIOWE DO PROMOCJI DZIAEAŃ NON PROFIT ORAZ ZWIĘKSZENIA SKUTECZNOŚCI FUNDACJI. PREZENTUJE WYNIKI BADAŃ MONITORINGU MEDIÓW NA TEMAT OBECNOŚCI WYBRANYCH FUNDACJI W INTERNECIE, A DLA SFORMUŁOWANIA ZASAD KOMUNIKACJI W SOCIAL MEDIA PODDAJĘ ANALIZIE KANAEY SOCIAL MEDIA NAJWIĘKSZYCH POLSKICH ORGANIZACJI POŻYTKU PUBLICZNEGO.
\end{abstract}

\section{SŁOWA KLUCZOWE:}

NON PROFIT, DOBROCZYNNOŚĆ, MEDIA SPOŁECZNOŚCIOWE, KOMUNIKACJA

\begin{abstract}
:
BASED ON EXAMPLES OF SOME PUBLIC BENEFIT ORGANIZATIONS (CATHOLIC AND SECULAR), AUTHOR SHOWS HOW TO USE THE SOCIAL MEDIA TOOLS TO PROMOTE NON-PROFIT ACTIVITIES AND THEREBY INCREASE THEIR EFFECTIVENESS. AUTHOR PRESENTS THE RESULTS OF MEDIA MONITORING ON THE PRESENCE OF SELECTED FOUNDATIONS ON THE INTERNET, AND TRY TO FORMULATE GOOD RULES OF COMMUNICATION IN SOCIAL MEDIA CHANNELS BY ANALYSIS THE LARGEST POLISH PUBLIC BENEFIT ORGANIZATIONS.
\end{abstract}

\section{KEYWORDS:}

NON-PROFIT ORGANIZATION, CHARITY, SOCIAL MEDIA, COMMUNICATION 
$\mathrm{C}$ elem tekstu jest prezentacja wybranych narzędzi mediów społecznościowych, które mogą posłużyć promocji działalności charytatywnej, a co za tym idzie, zwiększyć skuteczność organizacji non profit. Punktem wyjścia do podjęcia refleksji na temat social media w kontekście dobroczynności jest stosunek Polaków do fundacji charytatywnych, zarówno tych kościelnych, jak i świeckich. Następnie przedstawiona zostanie aktywność wybranych organizacji non profit w mediach internetowych. W tym celu korzystam z takich metod badawczych, jak analiza i synteza. Analizie poddaję kanały społecznościowe wybranych polskich organizacji charytatywnych. Dla uzyskania niezbędnych danych odwołuję się do monitoringu mediów przeprowadzonego z wykorzystaniem narzędzi firmy Newspoint. Na końcu formułuję w syntetyczny sposób dobre praktyki w social media, z których warto korzystać tworząc politykę komunikacyjną organizacji non profit.

\section{Teza, hipotezy badawcze}

Z podjętej analizy mediów społecznościowych wynika, że polskie organizacje charytatywne aktywnie korzystają z nowoczesnych kanałów komunikacji, dzięki czemu docierają z przekazem do szerokiego grona odbiorców. Skłania to do postawienia tezy, że umiejętne zastosowanie narzędzi social media może zwiększyć skuteczność organizacji non profit. Formułując hipotezy i problemy badawcze należy podkreślić opisane poniżej kwestie:

- stosunek Polaków do organizacji non profit jest pozytywny - co roku przeznaczają coraz większe kwoty na działalność wybranych fundacji,

- ważnym elementem polityki informacyjnej organizacji non profit jest obecność w internecie oraz w nowoczesnych kanałach komunikacji,

- umiejętne wykorzystanie narzędzi social media przez organizacje non profit wzmacnia komunikaty przekazywane w tradycyjnych mediach, może też skutkować zwiększeniem zasięgu organizacji i poszerzaniem grona odbiorców.

\section{Polacy wspierają organizacje pożytku publicznego}

Z danych Ministerstwa Finansów za poszczególne lata wynika, że Polacy chętnie przeznaczają pieniądze na fundacje dobroczynne. W zeznaniu podatkowym za 2012 r. aż 44\% Polaków (ok. 11,5 mln osób) przekazało odpis 1\% organizacjom pożytku publicznego (dalej: OPP). Głównymi beneficjantami ofiarności są fundacje działające na rzecz chorych dzieci i osób niepełnosprawnych. Polacy darzą zaufaniem organizacje kościelne oraz hospicja i fundacje wspierające osoby potrzebujące. Na konta ponad 7 tys. podmiotów wpłynęło $480 \mathrm{mln} \mathrm{zł}^{1}$.

Wśród 5. najchętniej wspieranych organizacji są: Fundacja Dzieciom „Zdążyć z pomocą" (117,2 mln zł), Fundacja Pomocy Osobom Niepełnosprawnym „Słoneczko” (15,3 mln zł), Avalon - Bezpośrednia Pomoc Niepełnosprawnym (8,5 mln zł), Fundacja „Rosa” (8 mln zł) oraz Fundacja Anny Dymnej „Mimo Wszystko” (6,2 mln zł). W pierwszej 30. beneficjentów $1 \%$ znalazło się wiele organizacji charytatywnych związanych z Kościołem katolickim i związkami wyznaniowymi. 2,9 mln zł (21. miejsce) otrzymała

\footnotetext{
${ }^{1}$ LK/Warszawa/KAI, 44 proc. Polaków wsparło organizacje pożytku publicznego, http://www.niedziela.pl/artykul/6526/44-proc-Polakow-wsparlo-organizacje, (dostęp: 28.12.2017 r.).
} 
Fundacja „Dzieło Nowego Tysiąclecia” (dalej: „DNT”), która tworzy fundusz stypendialny dla zdolnej młodzieży z ubogich rodzin. Na 23. miejscu znalazła się organizacja Caritas Polska, na którą Polacy przekazali 2,6 mln zł².

Jeszcze więcej pieniędzy organizacje otrzymały w kolejnych latach. Ze sprawozdania za rok 2013 wynika, że łączna kwota przekazana na rzecz OPP wyniosła 506,6 mln zł. Ponownie na pierwszym miejscu znalazła się fundacja „Zdążyć z pomocą” (ponad $127 \mathrm{mln}$ zł). W pierwszej 5. beneficjentów raport wymienia: „Słoneczko” (17,6 mln zł), Avalon (11,6 mln zł), „Rosę” (8,7 mln zł) oraz Fundację Nasza Szkoła (6,1 mln zł). Fundacja Anny Dymnej znalazła się na 8. miejscu (5,2 mln zł). OPP związane z Kościołem znalazły się poza pierwszą 30 . - Caritas na 35. pozycji (1,9 mln zł), Chrześcijańska Służba Charytatywna na 51. (1,3 mln zł), Dzieło Pomocy św. Ojca Pio na 52. (1,2 mln zł), „DNT” na 60 miejscu (1,1 mln zł $)^{3}$.

Sytuacja przedstawia się podobnie w rozliczeniu za następny rok. Łączna kwota $1 \%$ przekazana na rzecz OPP w 2014 wyniosła 557,6 mln zł. Pierwsze cztery miejsca pozostają bez zmian - „Zdążyć z pomocą” uzyskała wsparcie 136,1 mln zł, „Słoneczko” - 20,7 mln zł, Avalon - 15,7 mln zł, „Rosa” - 10,3 mln zł. Na 5. pozycji znalazła się Fundacja Studencka „Młodzi - Młodym” (8,2 mln zł). Na wysokiej 10. pozycji była związana z Radiem Maryja Fundacja „Nasza Przyszłość”. Caritas zajął 59. miejsce (1,3 mln zł), a „DNT” 119. miejsce $(555 \text { tys. })^{4}$.

\section{Wybrane organizacje non profit w social media - wyniki monitoringu mediów}

Celem tekstu jest zaprezentowanie wybranych narzędzi mediów społecznościowych, które mogą pomóc w zwiększeniu skuteczności organizacji non profit. Dla sformułowania zasad dotyczących polityki social media niezbędne jest podjęcie refleksji na temat działania wybranych OPP w nowoczesnych kanałach komunikacji. Przedmiotem analizy są fundacje kościelne, dlatego przeprowadziłam monitoring mediów internetowych dla Caritas Polska oraz „DNT”. Medialną politykę fundacji katolickich skonfrontuję ze strategią największych świeckich fundacji. Dla porównania wybrałam fundację Anny Dymnej oraz „Zdążyć z pomocą”, które utrzymują się w czołówce najchętniej wspieranych przez Polaków OPP.

Analizie poddaję ponadto działania promujące Szlachetną Paczkę. Wprawdzie sam projekt nie należy do kategorii OPP, jednak jest realizowany przez Stowarzyszenie „Wiosna”, które w 2014 znalazło się na 46. miejscu wspieranych przez Polaków organizacji (1,43 mln zł). Warto przyjrzeć się Szlachetnej Paczce, ponieważ organizacja prowadzi

\footnotetext{
${ }^{2}$ LK/Warszawa/KAI, 44 proc. Polaków..., dz. cyt.

${ }^{3}$ Ministerstwo Finansów, Informacja dotycząca kwot 1\% należnego podatku dochodowego od osób fizycznych przekazanych organizacjom pożytku publicznego z rozliczenia za 2013 rok, http://www.finanse.mf.gov.pl/documents/766655/2970107/Wykaz+organizacji+po \%C5\%BCytku+publicznego\%2C+kt\%C3\%B3re+w+2014+r.+otrzyma\%C5\%82y+1+proc., (dostęp: 28.12 .2017 r.).

${ }^{4}$ Ministerstwo Finansów, Informacja dotycząca kwot 1\% należnego podatku dochodowego od osób fizycznych przekazanych organizacjom pożytku publicznego z rozliczenia za 2014 rok, http://www.finanse.mf.gov.pl/documents/766655/5008832/Wykaz+organizacji+po\%C5\%BCytku+publicznego $\% 2 \mathrm{C}+\mathrm{kt} \% \mathrm{C} 3 \% \mathrm{~B} 3 \mathrm{re}+\mathrm{w}+2015+$ otrzyma\%C5\%82y+kwoty+1+proc., (dostęp: 28.12.2017 r.).
} 
profesjonalną komunikację w mediach społecznościowych, co odzwierciedlają statystyki . W 2014 (14. edycja) aktywność w dodawaniu postów akcji wzrosła o 76 proc. w stosunku do roku 2013. Aż 88\% wszystkich wzmianek w mediach na temat Szlachetnej Paczki pochodziło z Facebooka. Media tradycyjne dostarczają kilku procent komunikatów radio $(6 \%)$, prasa (4\%) oraz telewizja (2\%). Wzrost publikacji w 2014 wyniósł 33\% ogółem oraz $76 \%$ na Facebooku. Na drugim miejscu znalazł się Twitter (8\%), na kolejnych plus.google.com oraz inne (po $2 \%)^{5}$.

Dla uzyskania danych przeprowadziłam analizę mediów internetowych korzystając z narzędzi firmy Newspoint. Uzyskane materiały ukazały się w okresie pomiędzy 1 maja 2015 a 31 października 2015. Uwzględnione w badaniu serwisy to tradycyjne strony WWW, fora, blogi, społeczności, mikroblogi, opinie, video oraz zdjęcia. Za wybraną jednostkę analizy uznałam post zawierający przynajmniej jedno wystąpienie słowa kluczowego (w większości nazwy własne fundacji).

\section{- Fundacja Anny Dymnej „Mimo wszystko”}

W okresie sześciu miesięcy ukazało się 1580 publikacji. Większość z nich $(67,8 \%)$, to materiały z mediów społecznościowych. Na 2. pozycji znalazły się strony www $(28,2 \%)$, na kolejnych video $(1,6 \%)$, mikroblogi $(1,3 \%)$, fora $(0,6 \%)$, blogi $(0,3 \%)$ oraz opinie i zdjęcia (po $0,1 \%$ ).

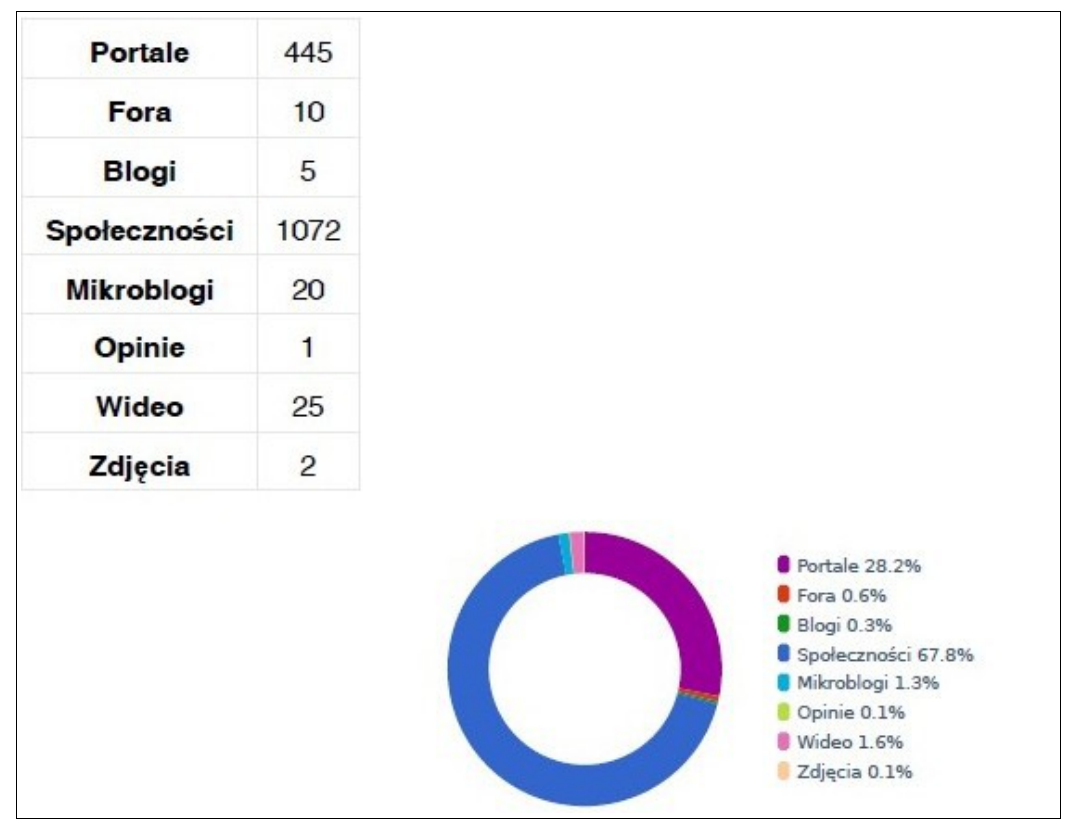

Grafika 1: Wzmianki o fundacji „Mimo wszystko” w badanym okresie (Newspoint.pl/badanie własne)

\footnotetext{
${ }^{5}$ M. Marchwicki, Szlachetna Paczka bije rekordy na Facebooku, http://socialpress.pl/2014/12/szlachetnapaczka-bije-rekordy-na-facebooku/, (dostęp: 28.12.2017 r.).
} 


\section{PUBLIC RELATIONS W INSTYTUCJACH NON-PROFIT}

Publikacje mają wydźwięk pozytywny (809). Za neutralne uznano 238 wypowiedzi, za negatywne - 1, z kolei 43 zostały zakwalifikowane jako nieocenione. Raport uwzględnia ponadto zmianę w liczbie i wydźwięku publikacji, jaką odnotowano w okresie analogicznym do badanego, ale bezpośrednio go poprzedzającym (tj. 1 grudnia 2014 - 30 kwietnia 2015). Publikacji przybyło o 144\%. Największy wzrost dotyczy komentarzy nieocenionych $290,9 \%$. Odnotowano wzrost materiałów pozytywnych o 163,5\%, neutralnych o 51,6\%. Komentarzy negatywnych było mniej o 66,7\%.

\begin{tabular}{c|c|c|c|c|c|}
\hline & Pozytywne & Neutralne & Negatywne & Nieocenione & Wszystkie \\
\hline $\begin{array}{c}\text { Liczba } \\
\text { wypowiedzi }\end{array}$ & 809 & 238 & 1 & 43 & 1091 \\
\hline Zmiana & $163.5 \%$ & $51.6 \%$ & $-66.7 \%$ & $290.9 \%$ & $144 \%$ \\
\hline
\end{tabular}

Grafika 2: Wydźwięk publikacji o fundacji „Mimo wszystko” (badanie własne/Newspoint.pl)

Największy wzrost publikacji da się zaobserwować pomiędzy 22. a 23. tygodniem, spadek ok. 26. tygodnia. Jeśli chodzi o miejsca, w których najczęściej pojawiały się wzmianki na temat fundacji, to widać, iż przeważa Facebook. Kolejne portale to Wosp.org, YouTube, Twitter, Polskie Radio, Onet.pl, Gazeta.pl. TVP, Interia oraz Super Express.

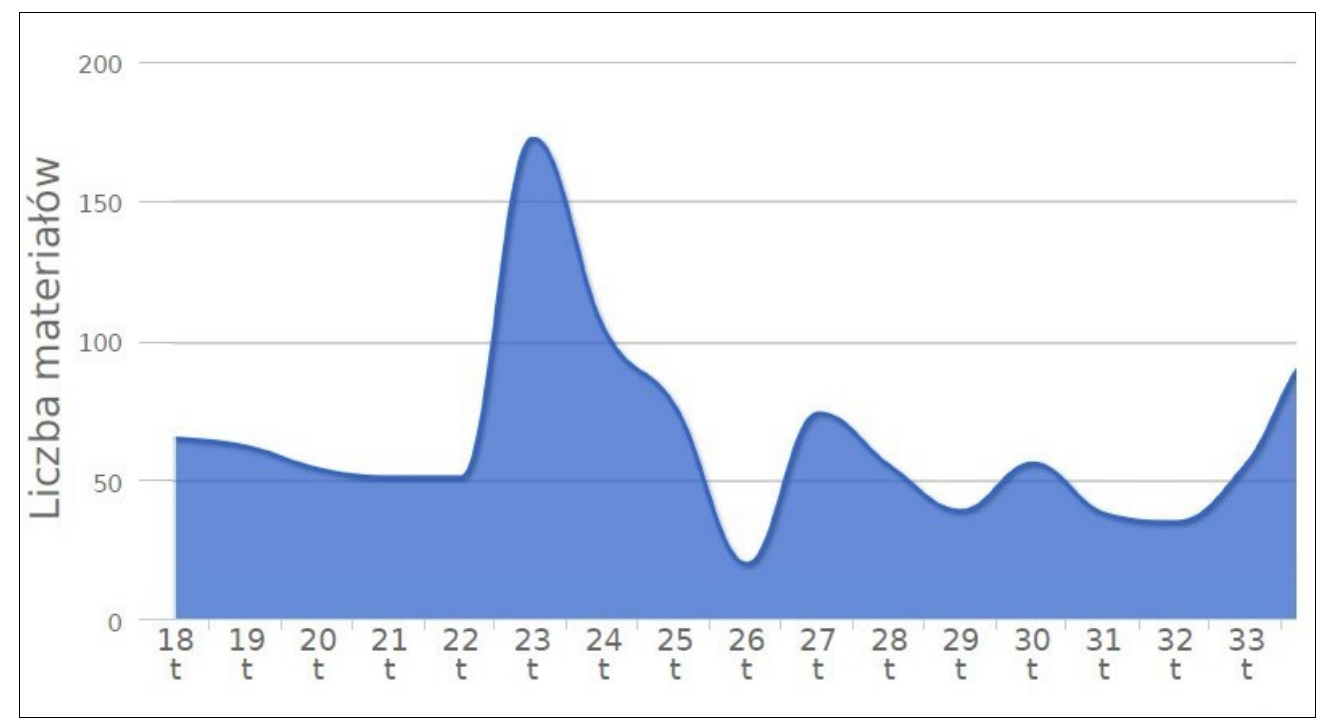

Grafika 3: Rozłożenie w czasie wyników dotyczących fundacji „Mimo wszystko” (badanie własne/Newspoint.pl) 


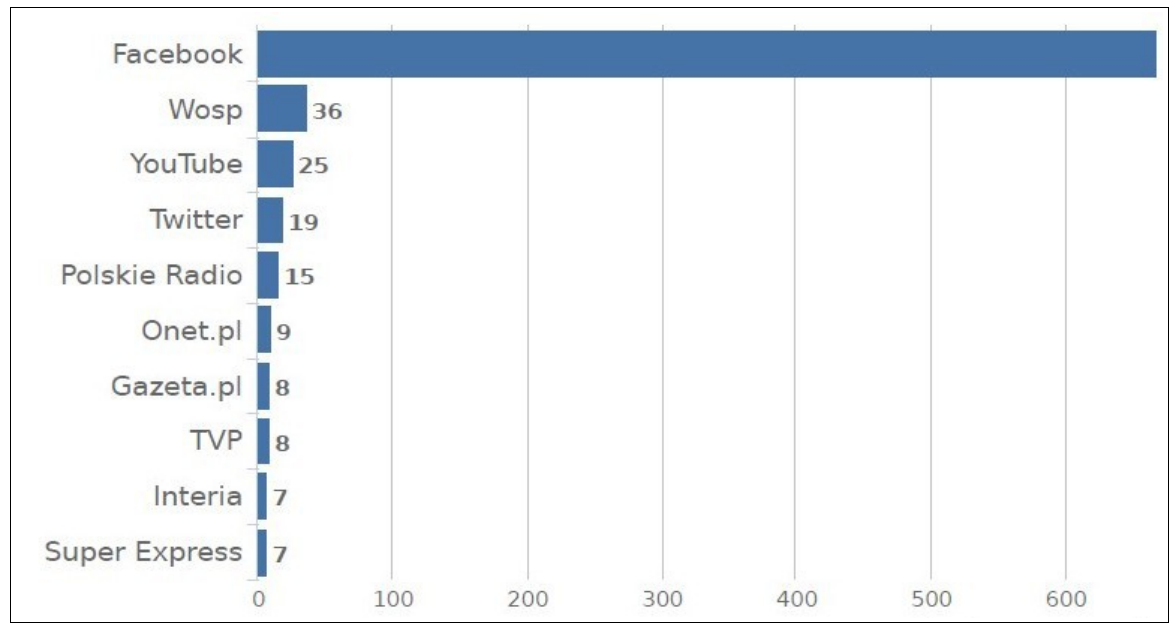

Grafika 4: Serwisy, w których najczęściej dyskutowano o fundacji „Mimo wszystko” (badanie własne/Newspoint.pl)

- Fundacja Dzieciom „Zdążyć z pomocą”

W badanym półroczu ukazało się 2816 materiałów, z których 2164 (76,8\%) to publikacje na Facebooku. Na stronach www ukazało się 19,5\% artykułów, na blogach 1,8\%, na forach $1 \%$. Materiały video to $0,6 \%$ oraz mikroblogi $-0,2 \%$ publikacji.

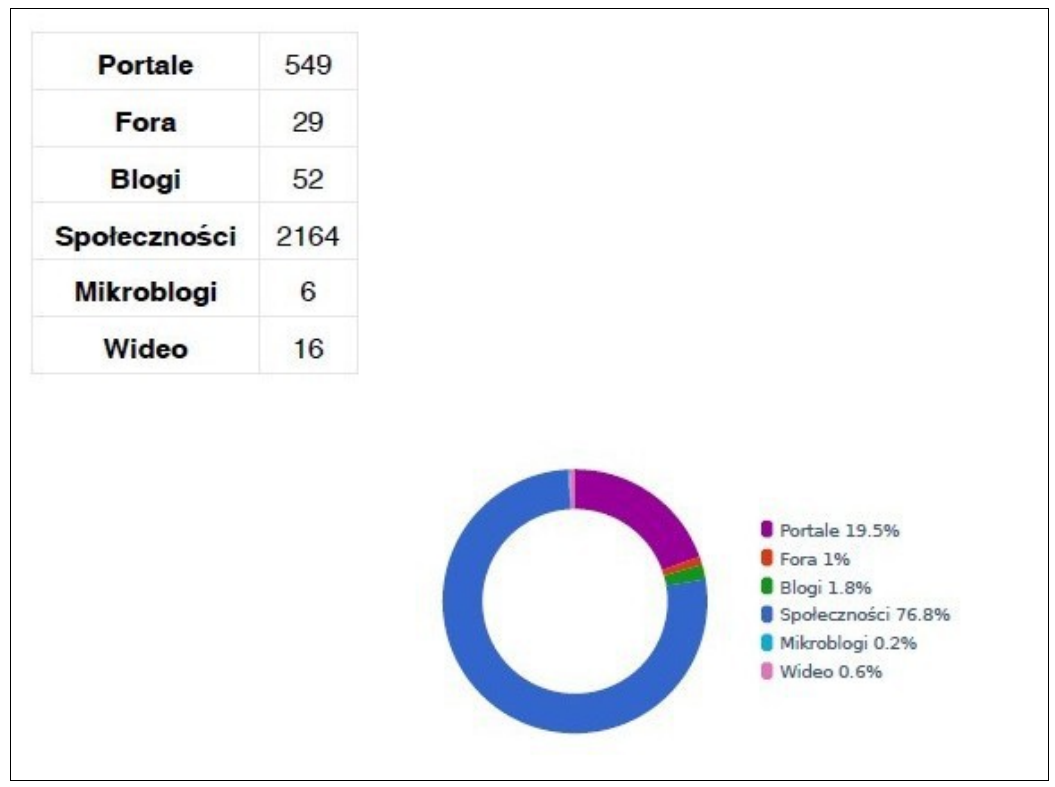

Grafika 5: Wzmianki o fundacji „Zdążyć z pomocą” w badanym okresie (badanie własne/Newspoint.pl) 


\section{PUBLIC RELATIONS W INSTYTUCJACH NON-PROFIT}

Większość materiałów (1958) zostało ocenionych jako neutralne, 399 jako pozytywne, zaś 301 jako negatywne. Za niemożliwe do oceny uznano 136 publikacji. Zmiana, która nastąpiła w analizowanym półroczu w stosunku do poprzedniego to $62 \%$, w tym: spadek negatywnych o $70,2 \%$, neutralnych o $67,7 \%$, pozytywnych o $58,4 \%$. Wzrosła liczba publikacji nieocenionych - o 33,3\%.

\begin{tabular}{|c|c|c|c|c|c|}
\hline \hline & Pozytywne & Neutralne & Negatywne & Nieocenione & Wszystkie \\
\hline $\begin{array}{c}\text { Liczba } \\
\text { wypowiedzi }\end{array}$ & 399 & 1958 & 301 & 136 & 2794 \\
Zmiana & $-58.4 \%$ & $-67.7 \%$ & $-70.2 \%$ & $33.3 \%$ & $-62 \%$ \\
\hline
\end{tabular}

Grafika 6: Wydźwięk publikacji o fundacji „Zdążyć z pomocą” (badanie własne/Newspoint.pl)

Największy wzrost publikacji odnotowano pomiędzy 18. a 19. tygodniem oraz pomiędzy 29. a 31. tygodniem, zaś największy spadek - w 27. tygodniu. Ponownie największa liczba podejmowanych dyskusji odnosiła się do Facebooka. Kolejne serwisy to: Blox, YouTube, Google+, Wirtualna Polska, Blog olx, TVP, Super Express, NGO.pl oraz Onet.pl.

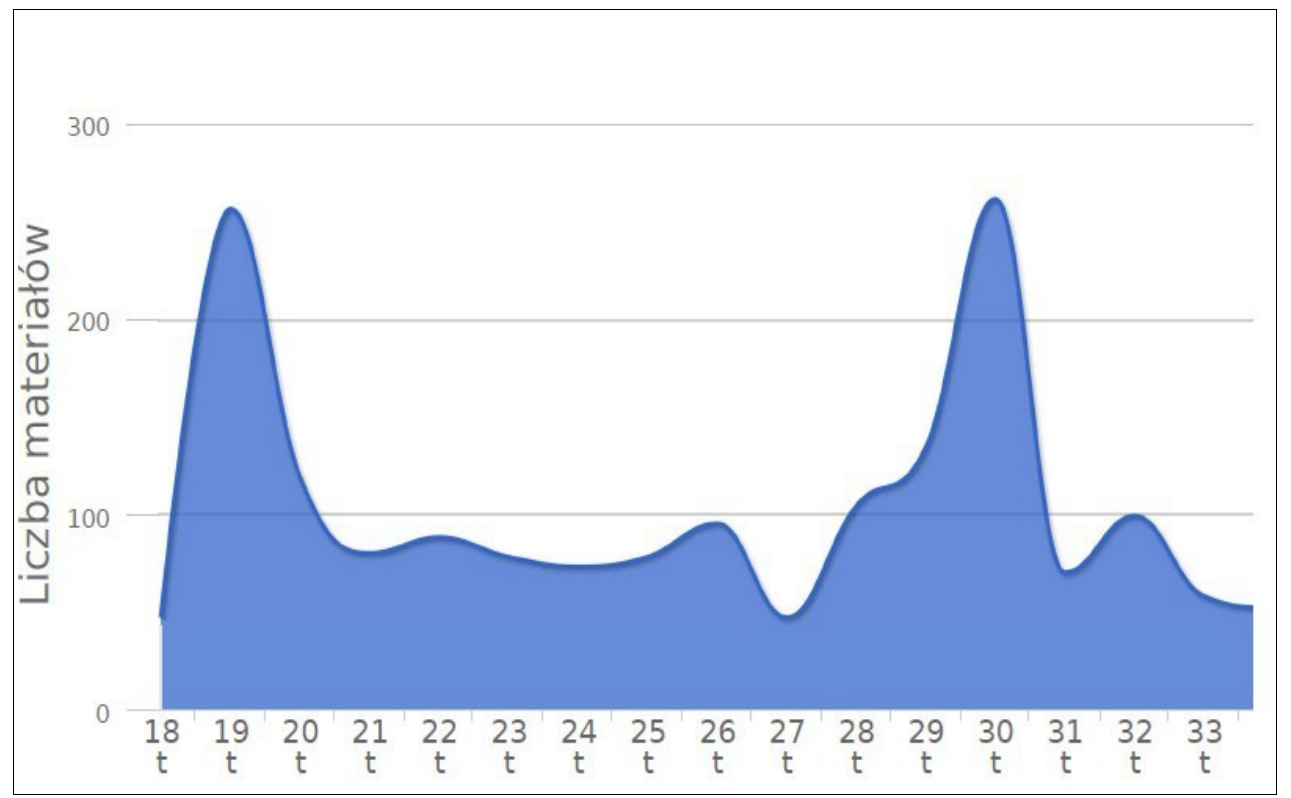

Grafika 7: Rozłożenie w czasie wyników fundacji „Zdążyć z pomocą” (badanie własne/Newspoint.pl) 


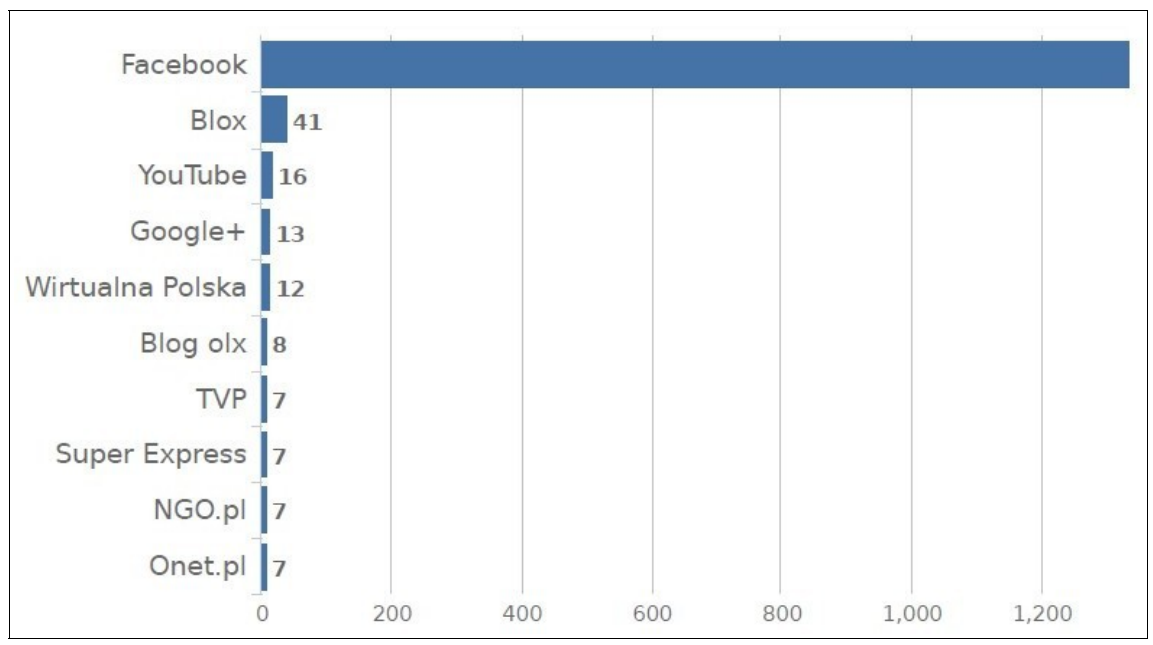

Grafika 8: Serwisy, w których najczęściej dyskutowano o fundacji „Zdążyć z pomocą” (badanie własne/Newspoint.pl)

\section{- Caritas Polska}

W analizowanym półroczu pojawiło się 3109 publikacji dotyczących tej kościelnej organizacji. W odróżnieniu od dwóch wyżej opisanych OPP, najwięcej materiałów ukazało się na stronach www $(52,7 \%)$. Kolejne miejsca to społeczności $(33,7 \%)$, fora internetowe $(5,5 \%)$, mikroblogi $(5,1 \%)$, video $(2,1 \%)$, blogi $(0,6 \%)$ oraz opinie $(0,3 \%)$.

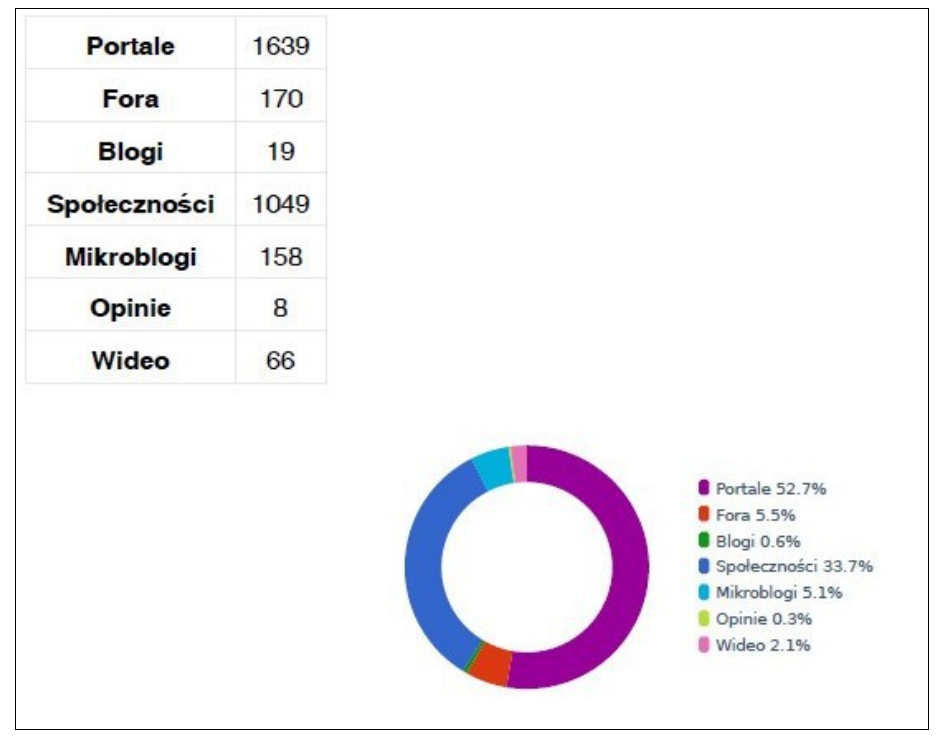

Grafika 9: Wyniki „Caritas” w badanym okresie (badanie własne/Newspoint.pl) 


\section{PUBLIC RELATIONS W INSTYTUCJACH NON-PROFIT}

Monitoring wykazał tyle samo publikacji o wydźwięku negatywnym i pozytywnym. Neutralnych odnotowano 9, zaś nieocenionych w ogóle. Zmiana w stosunku do półrocza poprzedzającego badany okres to wzrost publikacji o pozytywnych o $12,5 \%$ oraz spadek materiałów neutralnych o 87,1\%, negatywnych o 21,7\% (wszystkich - 021 proc.).

\begin{tabular}{|c|c|c|c|c|c|}
\hline \hline & Pozytywne & Neutralne & Negatywne & Nieocenione & Wszystkie \\
\hline $\begin{array}{c}\text { Liczba } \\
\text { wypowiedzi }\end{array}$ & 18 & 9 & 18 & 0 & 45 \\
Zmiana & $12.5 \%$ & $-87.1 \%$ & $-21.7 \%$ & $0.0 \%$ & $-21 \%$ \\
\hline
\end{tabular}

Grafika 10: Wydźwięk publikacji o „Caritas” (badanie własne/Newspoint.pl)

Najwięcej publikacji ukazało się pomiędzy 19. a 20. tygodniem analizowanego półrocza, zaś największy spadek nastąpił ok. 26. tygodnia. Liczba materiałów rozkładała się dość równomiernie. Wśród portali, na których najczęściej podejmowano dyskusję, pierwsze miejsce zajął Facebook. Na kolejnych pozycjach znalazły się Twitter, Ekai.pl, Tygodnik Idziemy, Tygodnik Katolicki Niedziela, YouTube, Wiara.pl, Stooq oraz Deon.pl.

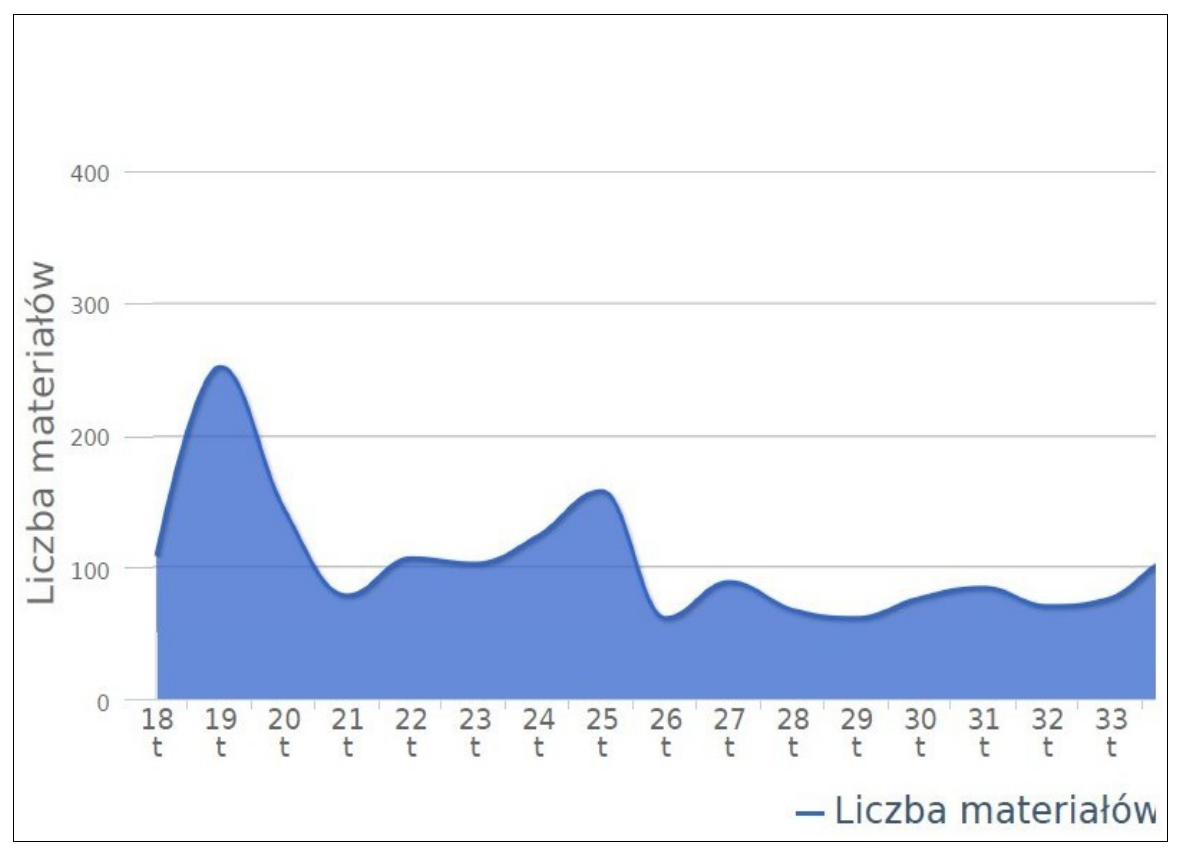

Grafika 11: Rozłożenie w czasie wyników „Caritas” (badanie własne/Newspoint.pl) 


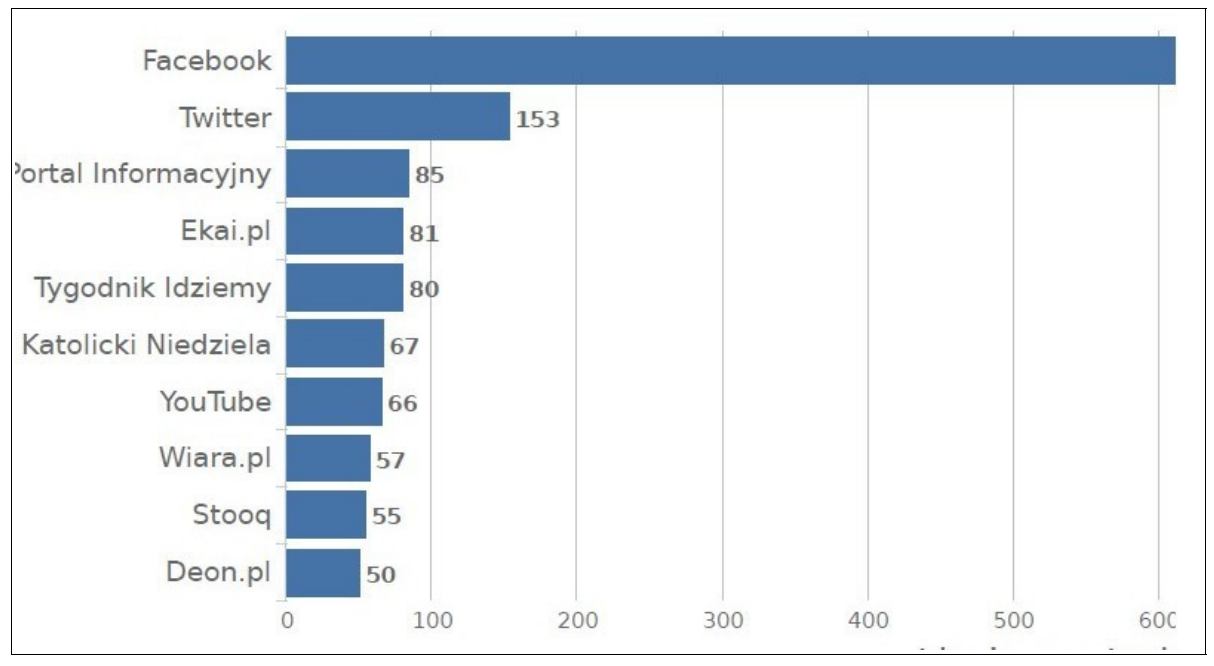

Grafika 12: Serwisy, w których najczęściej dyskutowano o „Caritas” (badanie własne/Newspoint.pl)

- Fundacja „Dzieło Nowego Tysiąclecia”

Fundacja chętnie komunikuje się za pośrednictwem nowoczesnych kanałów, o czym świadczą wyniki monitoringu. W mediach internetowych ukazało się 1091 publikacji, z których większość opublikowano w serwisach społecznościowych $(55,5 \%)$ oraz na stronach www (39\%). Pozostałe wyniki dotyczą mikroblogów $(2,1 \%)$, video $(1,6 \%$ ), forów (1,3\%) oraz opinii i blogów (po $0,3 \%$ ).

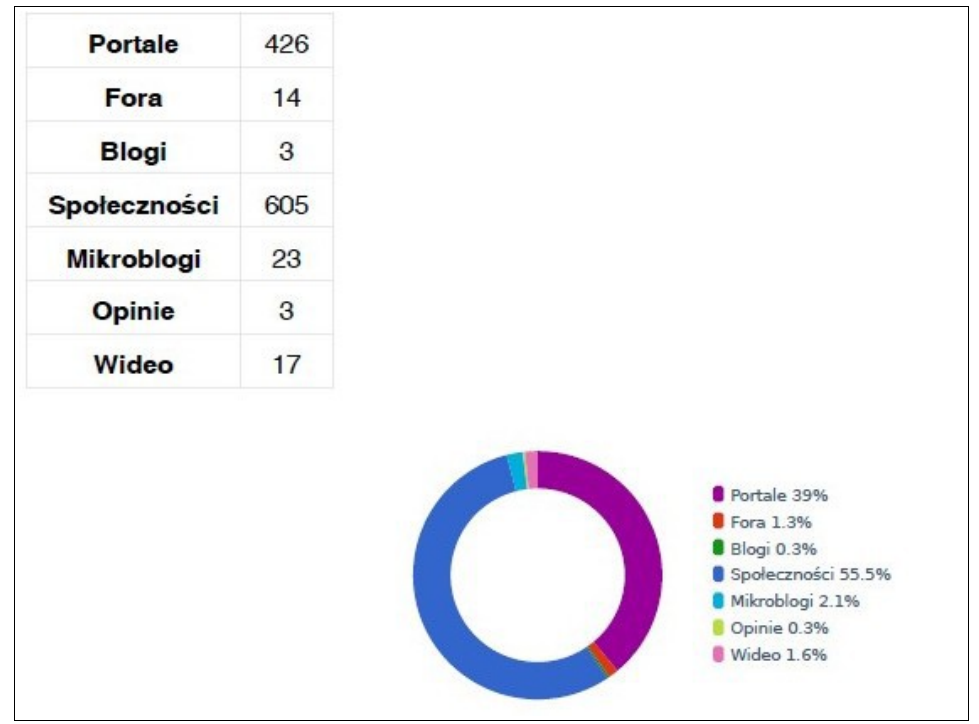

Grafika 13: Wyniki „DNT” w badanym okresie (badanie własne/Newspoint.pl) 


\section{PUBLIC RELATIONS W INSTYTUCJACH NON-PROFIT}

Są to przeważnie materiały o wydźwięku pozytywnym (809). Publikacji neutralnych odnotowano 238, negatywnych - 1 . Zmiana, która nastąpiła w liczbie i wydźwięku materiałów w stosunku do wcześniejszego półrocza, wyniosła wzrost publikacji pozytywnych o $163,5 \%$, neutralnych o $51,6 \%$, zaś nieocenionych o $290,9 \%$. Negatywnych wypowiedzi ubyło o $66,7 \%$. Ogółem liczba materiałów wzrosła o $144 \%$.

\begin{tabular}{|c|c|c|c|c|c|}
\hline & Pozytywne & Neutralne & Negatywne & Nieocenione & Wszystkie \\
\hline $\begin{array}{c}\text { Liczba } \\
\text { wypowiedzi }\end{array}$ & 809 & 238 & 1 & 43 & 1091 \\
\hline Zmiana & $163.5 \%$ & $51.6 \%$ & $-66.7 \%$ & $290.9 \%$ & $144 \%$ \\
\hline
\end{tabular}

Grafika 14: Wydźwięk publikacji o „DNT” (badanie własne/Newspoint.pl)

Publikacje publikacje ukazywały się nieregularnie. Widać wyraźny skok ok. 30. tygodnia, co może być związane z obchodzonym w tym czasie Dniem Papieskim. Największa liczba publikacji ukazała się na Facebooku. Pozostałe miejsca to: Ekai.pl, Tygodnik Idziemy, Tygodnik Katolicki Niedziela, TVP, Twitter, YouTube, Polskie Radio, Deon.pl, Wiara.pl.

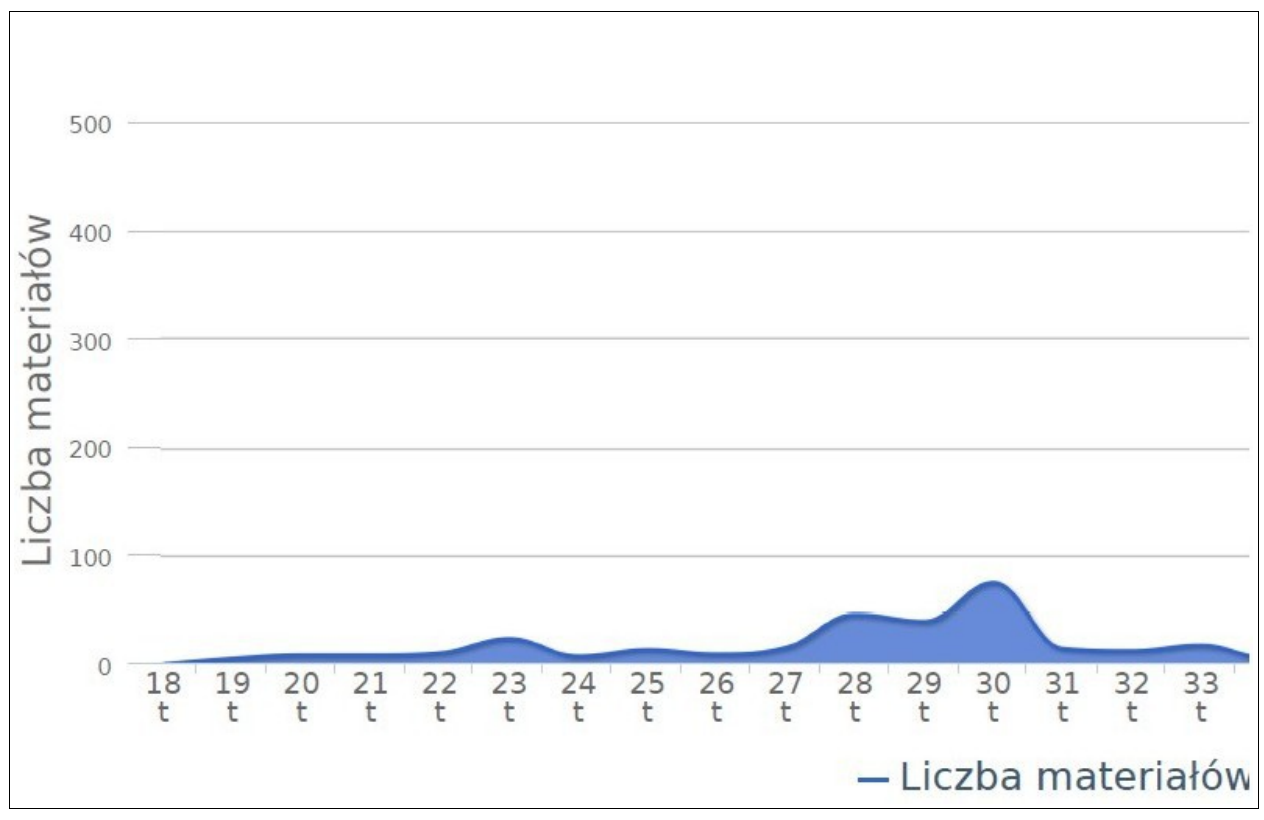

Grafika 15: Rozłożenie w czasie publikacji o „DNT” (badanie własne/Newspoint.pl) 


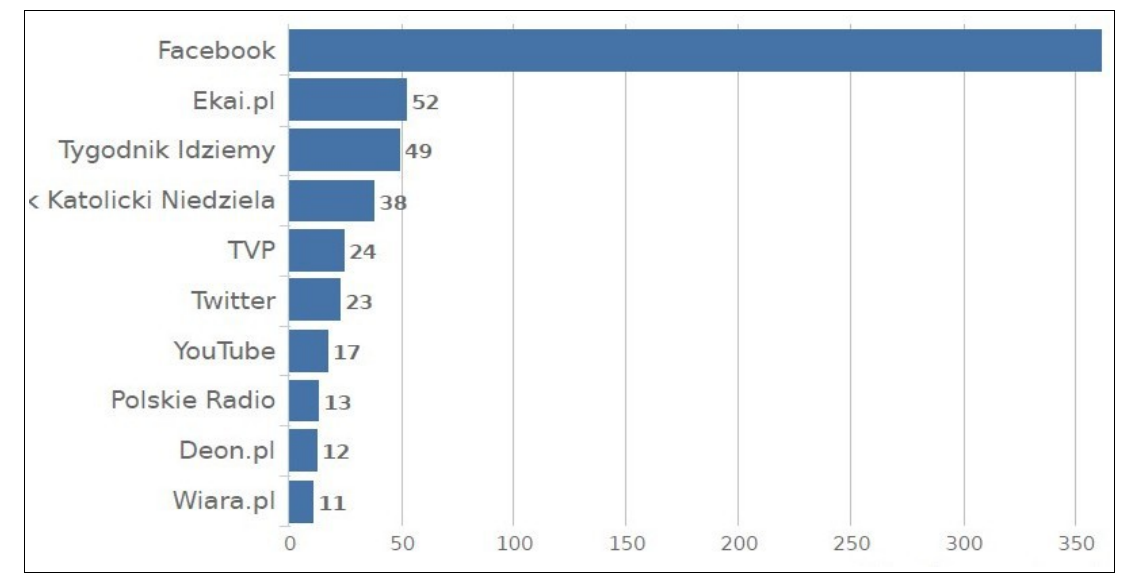

Grafika 16: Serwisy, w których najczęściej dyskutowano o „DNT” (badanie własne/Newspoint.pl)

\section{- Szlachetna Paczka}

Pisząc o komunikacji OPP w social media trudno pominąć Szlachetną Paczkę, która prezentuje wzorcową politykę obecności w serwisach społecznościowych. Liczba wyników uzyskanych w raporcie (473) może nie oddawać w pełni aktywności organizacji. W badaniu zostały uwzględnione tylko te publikacje, które prócz słów kluczowych „Szlachetna Paczka”, zawierały imię i nazwisko inicjatora projektu, czyli ks. Jacka Stryczka, co mogło wpłynąć na zmniejszenie wyników.

Materiały ukazywały się w mediach społecznościowych (52\%) oraz na stronach www $(41,2 \%)$. Kolejne typy serwisów to: fora internetowe $(3,4 \%)$, blogi $(1,7 \%)$, video $(1,1 \%)$ oraz mikroblogi $(0,6 \%)$.

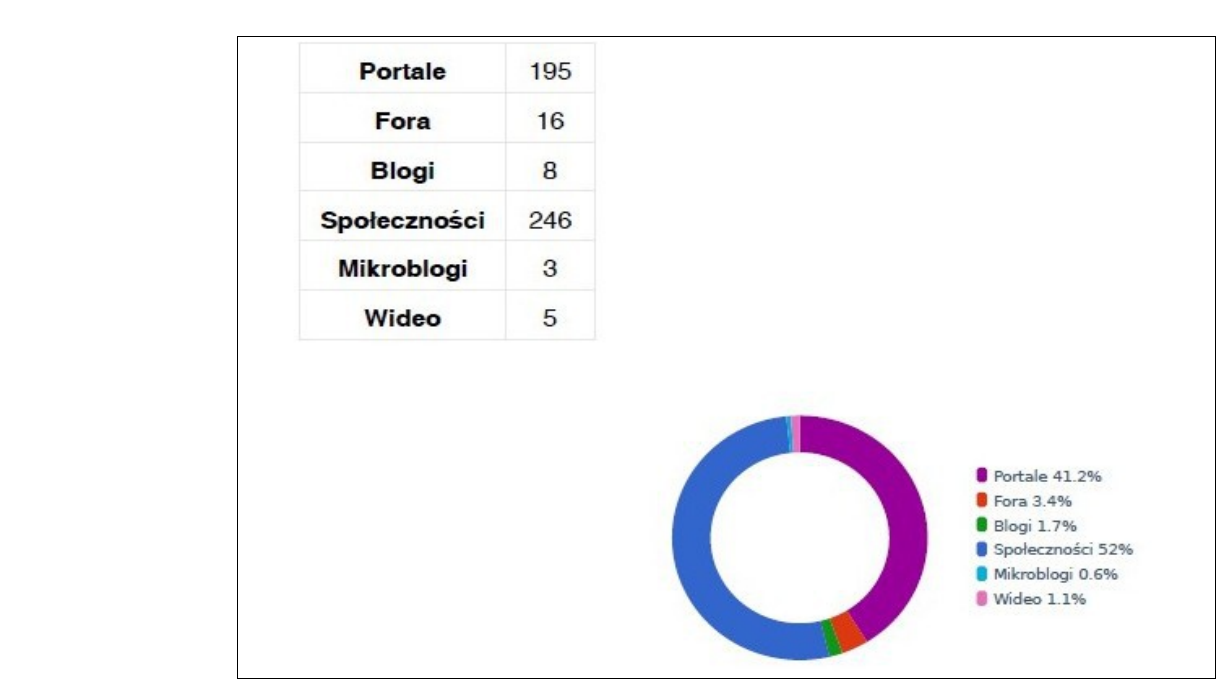

Grafika 17: Serwisy, w których najczęściej dyskutowano o „Szlachetnej Paczce” (badanie własne/Newspoint.pl) 


\section{PUBLIC RELATIONS W INSTYTUCJACH NON-PROFIT}

Najwięcej publikacji (237) oceniono jako neutralne. Wydźwięk pozytywny posiada 135 publikacji, zaś negatywny - 101. Zmiana, która nastąpiła w stosunku do półrocza poprzedzającego badany okres, to spadek wszystkich publikacji o 32\%. Materiałów pozytywnych ubyło o 42,8\%, neutralnych o $61,7 \%$. Liczba postów negatywnych wzrosła o 50,7\%.

\begin{tabular}{|c|c|c|c|c|c|}
\hline & Pozytywne & Neutralne & Negatywne & Nieocenione & Wszystkie \\
\hline $\begin{array}{c}\text { Liczba } \\
\text { wypowiedzi }\end{array}$ & 135 & 237 & 101 & 0 & 473 \\
\hline Zmiana & $-42.8 \%$ & $-61.7 \%$ & $50.7 \%$ & $0.0 \%$ & $-32 \%$ \\
\hline
\end{tabular}

Grafika 18: Wydźwięk publikacji o „Szlachetnej Paczce” (badanie własne/Newspoint.pl)

Największe spadki publikacji zaobserwowano ok. 28. i 32. tygodnia, natomiast skoki pomiędzy 21. a 27. tygodniem. Jeśli chodzi o serwisy, w których najczęściej pojawiały się wzmianki, pierwsze miejsce zajął Facebook. Kolejne pozycje to: Wirtualna Polska, Deon.pl, YouTube, Blog olx, Tygodnik Podhalański, Wiara.pl, Onet.pl oraz Dziennik.pl.

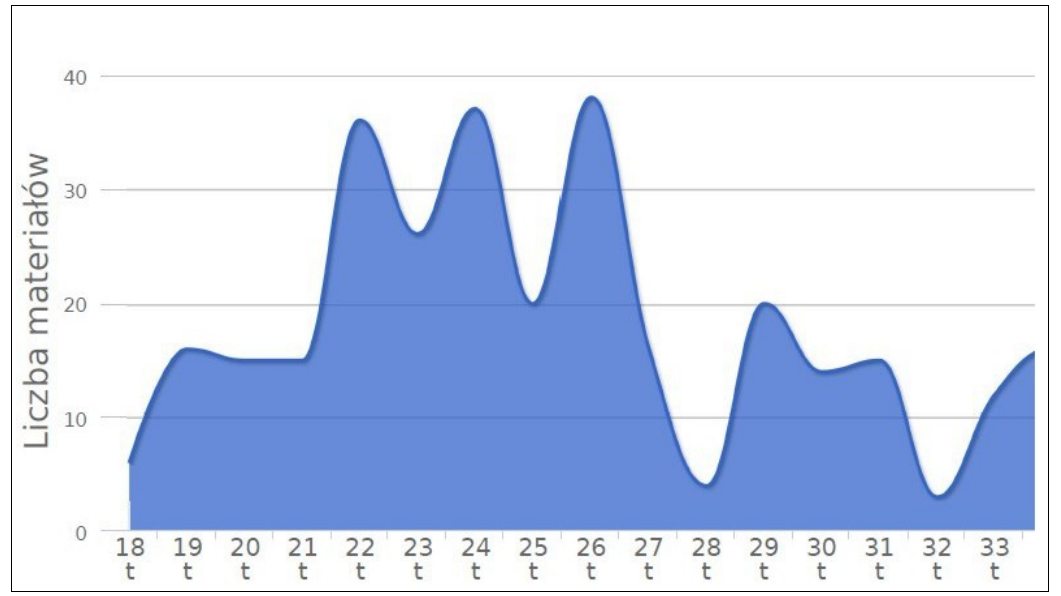

Grafika 19: Rozłożenie w czasie publikacji o „Szlachetnej Paczce” (badanie własne/Newspoint.pl)

\section{Porównanie wyników, wnioski}

Z miesięcznego zestawienia badanych OPP wynika, że fundacje odnotowują wzrosty i spadki publikacji w określonych przedziałach czasowych. Najbardziej równomiernie prezentują się wyniki Caritas Polska - liczba materiałów w każdym miesiącu nie jest mniejsza, niż 250. We wrześniu odnotowano nagły wzrost, co mogło być związane z zaangażowaniem Caritas w pomoc dla migrantów i uchodźców ${ }^{6}$ oraz podsumowaniem lokalnych akcji w diecezjach, w ramach których zbierano fundusze na szkolne wyprawki dla dzieci.

\footnotetext{
${ }^{6}$ Caritas Polska, Komunikat Caritas Polska w sprawie działań na rzecz uchodźców, http://www.caritas.pl/komunikat-caritas-polska-w-sprawie-dzialan-na-rzecz-uchodzcow/, (dostęp: 28.12.2017 r.).
} 


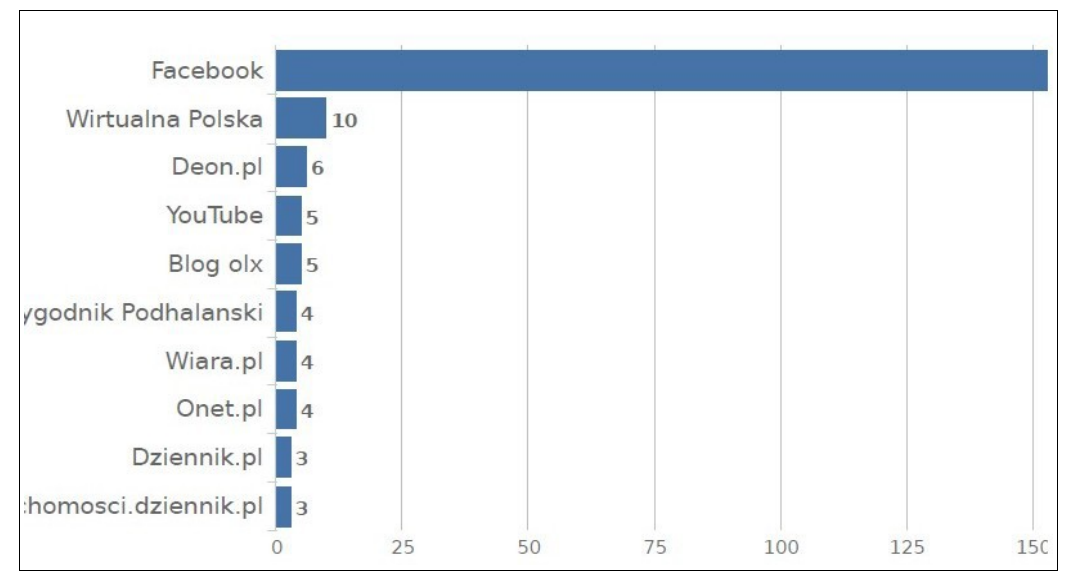

Grafika 20: Serwisy, w których najczęściej dyskutowano o „Szlachetnej Paczce” (badanie własne/Newspoint.pl)

Równomiernie rozkładają się też wyniki fundacji Anny Dymnej - pomiędzy 250 a 500. Największe spadki odnotowano w czerwcu i sierpniu. W sezonie letnim da się jednak zaobserwować ogólny spadek liczby materiałów dotyczących wszystkich analizowanych OPP, co jest najprawdopodobniej związane z wakacjami.

Nieregularnie wyglądają wyniki „DNT” - od maja do sierpnia ukazuje się niewiele materiałów, natomiast gwałtowny wzrost przypada na październik. Jest to związane z Dniem Papieskim - kulminacją działań fundacji. Z tej okazji odbywa się wiele imprez chętnie opisywanych w mediach, nie tylko katolickich. W październiku przyznawane są również stypendia dla zdolnej młodzieży z ubogich rodzin.

Liczba materiałów odnośnie do Szlachetnej Paczki jest w badanym okresie znikoma, co wynika z faktu, że inicjatywa odbywa się w grudniu - podarunki dla potrzebujących są rozdawane przed świętami Bożego Narodzenia. W raporcie zastosowano ponadto zbyt szczegółowe słowa kluczowe (imię i nazwisko ks. Jacka Stryczka), co zaniżyło wyniki.

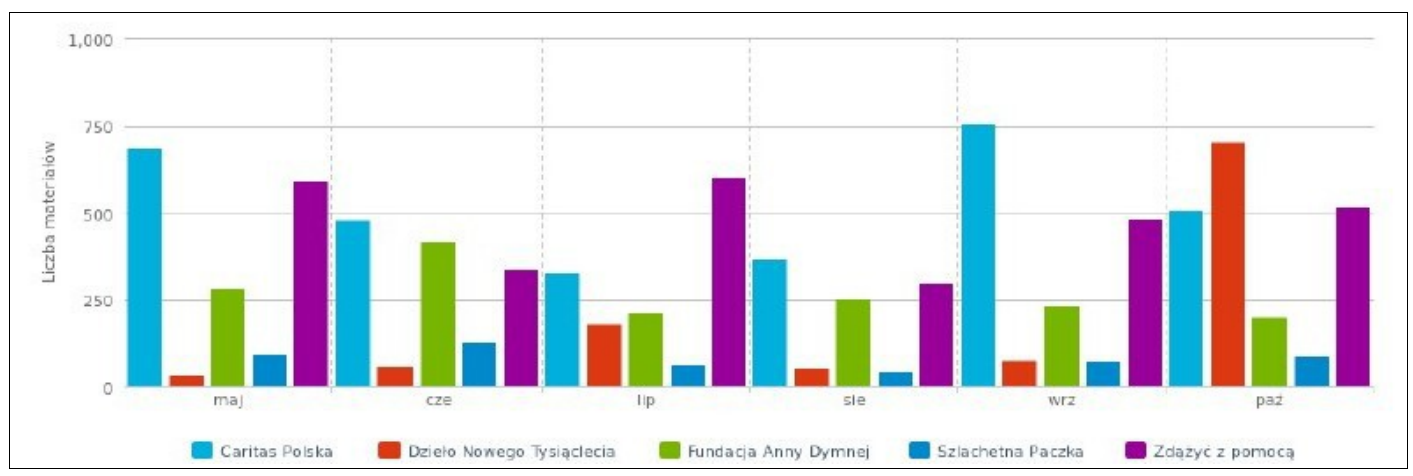

Grafika 21: Porównanie wyników wszystkich fundacji (badanie własne/Newspoint.pl) 
Serwisem, w którym najchętniej dyskutowano o wybranych OPP był Facebook (ponad 5 tys. publikacji), co potwierdza tezę, że dobroczynność jest zagadnieniem często pojawiającym się w mediach społecznościowych. Znaczna przewaga Facebooka nad innymi portalami może wynikać z metody zliczania wyników, która uwzględnia nie tylko posty (statusy), ale również komentarze zawierające słowa kluczowe. Nie zaburza to jednak znacząco ogólnego wyniku, ponieważ użytkownik Facebooka może określić zasięg wpisów ograniczając widoczność do grona znajomych, a posty prywatne nie są uwzględniane w zestawieniu. Ponadto, jeśli zastosowana metoda uwzględnia nie tylko artykuły na stronach www, ale również komentarze internautów, pojawią się one w ogólnym zestawieniu, równoważąc wysokie wyniki z social media.

O przewadze mediów społecznościowych w dyskusji na temat OPP decyduje również 2. miejsce, na którym znalazł się Twitter oraz zamykający pierwszą piątkę YouTube. Pozostałe portale przodujące w zestawieniu to serwisy katolickich czasopism oraz religijne portale, jak Ekai.pl, Deon.pl, Wiara.pl, Opoka, witryna tygodnika „Niedziela”, „Idziemy” czy „Gościa Niedzielnego”. W raporcie pojawiają się również ogólnopolskie media informacyjne, jak TVN24 czy Polskie Radio.

\section{Wybrane narzędzia social media a promocja działań organizacji non profit}

Obecność w social media jest niezbędnym elementem polityki medialnej OPP. Komunikaty w mediach tradycyjnych oraz internetowych to sposób dotarcia do odbiorców i promowania dobroczynności, a także pozyskiwania środków. O potędze mediów społecznościowych świadczą rosnące liczby użytkowników - na samym Facebooku konto posiada 14 milionów polskich internautów ${ }^{7}$. Spędzają oni w internecie i mediach społecznościowych średnio 4,4 godziny (desktop) i 1,3 godziny (mobile) każdego dnia ${ }^{8}$.

Media społecznościowe służą wzmocnieniu przekazów wysyłanych za pośrednictwem tradycyjnych kanałów komunikacji. Warto zastanowić się nad tym, jak umiejętnie korzystać z wybranych narzędzi social media, aby zwiększyć skuteczność OPP. Prezentując poszczególne narzędzia (zaczynając od czynności najprostszych i stopniowo przechodząc do bardziej zaawansowanych aktywności), podaję przykłady działań wybranych fundacji.

- Szybkie odpisywanie na wiadomości (także z katalogu „Inne”, jak w przypadku Facebooka) jest podstawą w mediach społecznościowych. Służy to budowaniu relacji pomiędzy użytkownikami i usprawnia komunikację ${ }^{9}$. Fanpage'e zawierają informację (lewy górny róg strony) o tym, jak szybko dany podmiot odpisuje na wiadomości (dla przykładu - Caritas Polska robi to „bardzo sprawnie”).

\footnotetext{
${ }^{7}$ Ł. Dębski, Statystyki Facebooka w Polsce. Stan na 08.2016, http://www.infosocialmedia.pl/statystykifacebooka-w-polsce-2q-2016/, (dostęp: 09.12.2017 r.).

${ }^{8}$ M. Gwóźdź, Liczby polskiego internetu 2016, http://zblogowani.pl/wpis/2023462/liczby-polskiegointernetu-2016, (dostęp: 09.12.2017 r.).

${ }^{9}$ Zob. M. Pełechaty, Społeczności internetowe, w: K. Pankiewicz (red.), E-marketing w akcji, Gliwice 2008, s. 151,165 .
} 
M. Brzezińska-Waleszczyk, Jak zwiększyć skuteczność organizacji non profit...

\begin{tabular}{|c|c|c|c|c|c|c|c|}
\hline 类 & 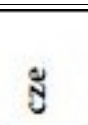 & $\cong$ & $\frac{\oplus}{\infty}$ & $\frac{N}{3}$ & 式 & & 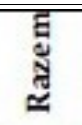 \\
\hline Wszystkie & 1677 & 1409 & 1369 & 993 & 1605 & 1991 & 9044 \\
\hline Facebook & 1026 & 805 & 897 & 599 & 771 & 1001 & 5099 \\
\hline Twitter & 27 & 36 & 31 & 11 & 41 & 56 & 202 \\
\hline Ekai.pl & 23 & 23 & 8 & 8 & 18 & 56 & 136 \\
\hline Tygodnik Idziemy & 12 & 21 & 14 & 9 & 24 & 51 & 131 \\
\hline YouTube & 15 & 19 & 47 & 24 & 6 & 18 & 129 \\
\hline Tygodnik Katolicki Niedziela & 9 & 16 & 12 & 11 & 22 & 40 & 110 \\
\hline Sądecki Portal Informacyjny & 6 & 2 & 2 & 2 & 76 & 7 & 95 \\
\hline Wiara.pl & 17 & 13 & 6 & 4 & 19 & 17 & 76 \\
\hline Deon.pl & 5 & 11 & 10 & 8 & 18 & 17 & 69 \\
\hline Wirtualna Polska & 6 & 10 & 29 & 8 & 10 & 6 & 69 \\
\hline TVP & 10 & 7 & 8 & 10 & 11 & 21 & 67 \\
\hline Stooq & 12 & 16 & 4 & 6 & 14 & 14 & 66 \\
\hline Polskie Radio & 11 & 10 & 2 & 4 & 9 & 26 & 62 \\
\hline Stooq & 13 & 12 & 4 & 6 & 12 & 12 & 59 \\
\hline Opoka & 6 & 9 & 5 & 4 & 22 & 8 & 54 \\
\hline Onet.pl & 7 & 15 & 7 & 8 & 8 & 9 & 54 \\
\hline Gazeta.pl & 16 & 13 & 6 & 7 & 4 & 7 & 53 \\
\hline Radio Maryja & 16 & 9 & 4 & 6 & 6 & 6 & 47 \\
\hline TVN24 & 8 & 5 & 0 & 1 & 5 & 27 & 46 \\
\hline Blox & 9 & 9 & 6 & 4 & 10 & 7 & 45 \\
\hline Gość Niedzielny & 10 & 6 & 1 & 1 & 13 & 9 & 40 \\
\hline Wosp & 1 & 1 & 21 & 10 & 3 & 0 & 36 \\
\hline Google+ & 6 & 4 & 5 & 5 & 5 & 10 & 35 \\
\hline RMF24 & 23 & 2 & 1 & 0 & 2 & 3 & 31 \\
\hline Polskie Radio PiK & 11 & 9 & 0 & 2 & 3 & 5 & 30 \\
\hline Pozostale & 372 & 326 & 239 & 235 & 473 & 558 & 2203 \\
\hline
\end{tabular}

Grafika 22: Serwisy, w których najczęściej dyskutowano o badanych fundacjach ogółem (badanie własne/Newspoint.pl) 
- Szybkie reagowanie na komentarze użytkowników oraz ich posty (o ile opcja nie została wyłączona przez administratorów) to fundament kształtowania dobrych relacji $\mathrm{z}$ fanami ${ }^{10}$ oraz budowania grupy zaangażowanych użytkowników (najbardziej wartościowych z punktu widzenia organizacji) ${ }^{11}$. Użytkownicy social media chcą, by traktować ich jak ludzi, a nie jak cyferki na liczniku fanów. Chcą, żeby ich słuchać, nie tylko oferować produkt/usługę (tutaj: proponować wpłatę na określone konto) ${ }^{12}$. Kwestią priorytetową w social media jest człowiek i nawiązywanie relacji ${ }^{13}$.

- Zamieszczanie postów zawierających grafikę, zdjęcie, rysunek, mem. Z obserwacji mechanizmów Facebooka wynika, że wpisy z ilustracją są chętniej udostępniane, aniżeli posty tekstowe. Z analizy fanpage'y wybranych fundacji wynika, że prawie w ogóle nie umieszczają one postów wyłącznie tekstowych.

- Regularna publikacja postów to forma podtrzymania kontaktu z odbiorcami. Strony, na których posty ukazują się rzadziej niż raz dziennie/co drugi dzień, są dla użytkowników mało atrakcyjne. Ideałem byłoby zamieszczanie ok. 3 postów dziennie na Facebooku i 5-7 wpisów na Twitterze ${ }^{14}$ (w godzinach, w których użytkownicy są najbardziej aktywni, co można sprawdzić w statystykach strony) Z częstotliwością wpisów należy uważać - spamowanie może skutkować odlajkowaniem strony.

- Publikacja informacji z branży. Prowadząc fanpage nie trzeba się ograniczać do zamieszczania postów dotyczących własnej działalności ${ }^{15}$. Monotematyczność (linki do materiałów ze strony www fundacji) nie zachęci użytkowników do zwiększania wpłat na rzecz OPP. Warto publikować informacje o innych organizacjach non profit, ale również linki do blogów i ciekawych materiałów znalezionych $\mathrm{w}$ sieci $^{16}$. Można też odwołać się do stron o całkiem innym profilu. Dla przykładu na fanpage’u Caritas można znaleźć link do tekstu z Natemat.pl ${ }^{17}$, który bywa uznawany za portal krytykujący Kościół.

\footnotetext{
${ }^{10}$ Zob. J. Gitomer, Społecznościowy boom! Wykorzystaj potencjał sieci e-kontaktów do wykreowania marki, zwiększenia sprzedaży i zdominowania rynku, Gliwice 2012, s. 60-66.

${ }^{11}$ Zaangażowani użytkownicy to internauci, którzy nie tylko dodali fanpage do ulubionych, ale aktywnie reagują na dodawane treści - lajkują, komentują, a przede wszystkim udostępniają posty, przez co zwiększają ich zasięg.

${ }^{12}$ S. Axelrod, Stop Reading About Social Media Trends And Start Listening, http://techcrunch.com/2015/12/22/stop-reading-about-social-media-trends-and-start-listening/, (dostęp: 30.12.2017 r.).

${ }^{13}$ Zob. W. Gustowski, Komunikacja w mediach społecznościowych, Gdynia 2012, s. 47-48.

${ }^{14}$ FaniMani.pl, Jak prowadzić działania na Twitterze - poradnik dla non profit cz.2, https://fanimani.pl/blog/jak-prowadzic-dzialania-na-twitterze-poradnik-dla-non-profit-cz-2/, (dostęp: 30.12.2017 r.).

${ }^{15}$ FaniMani.pl, Jak prowadzić..., dz. cyt.

${ }^{16}$ FaniMani.pl, Jak prowadzić..., dz. cyt.

${ }^{17}$ Screen w posiadaniu Autorki.
} 
- Treści wartościowe dla fanów ${ }^{18}$. Aby wyjść poza komunikację wyłącznie o własnej działalności i sukcesach, ale jednak pozostać w kręgu tematyki dobroczynności, można zamieszczać treści wartościowe z punktu widzenia użytkowników - na przykład wskazówki, jak dokonać odpisu 1\% lub dopełnić kwestii formalnych czy porady, jak skorzystać z pomocy (fundacja „Zdążýc z pomocą” proponowała artykuł o zasadach przyznawania zasiłku stałego ${ }^{19}$ ).

- Ludzkie historie. Aby uniknąć przesadnej autopromocji, warto pisać o ludziach - na przykład, kim są wolontariusze fundacji ${ }^{20}$, dlaczego zaangażowali się w działalność charytatywną, jak praca wpłynęła na ich życie. Ciekawe dla czytelników będą wiadomości o osobach, którym udało się pomóc - krótkie notatki oraz fotografie podopiecznych fundacji, stypendystów, dzieci, którym zakupiono niezbędny do leczenia sprzęt. Tym, co przyciąga uwagę odbiorców każdego medium są tzw. human stories ${ }^{21}$.

- Stosowanie oznaczeń. Dla zwiększenia zasięgu strony warto oznaczać konta osób publicznych czy innych organizacji poprzedzając je znakiem „@” (automatycznie pojawia się odwołanie do witryny ${ }^{22}$. To skuteczny zabieg w przypadku oznaczania dużych fanpage'y, jak papieża Franciszka (180 tys. polubień) czy Agnieszki Radwańskiej (900 tys. polubień). Dla Caritas Polska i Szlachetnej Paczki, które oznaczyły wspomniane fanpage'e w swoich postach, to szansa na zwiększenie zasięgu i zachęcenie followersów papieża i tenisistki do włączenia się w działalność charytatywną. Dobrym sposobem jest zaprzyjaźnienie się ze znanymi blogerami i youtuberami, czyli osobami popularnymi w social media. Zaproszenie ich do bycia ambasadorami projektu albo choćby sfotografowanie się z nimi (z oznaczeniem ich kont przez „@”), to kolejny sposób na dotarcie do nowych użytkowników ${ }^{23}$.

- Dziękowanie. Do podstaw społecznościowego savoir vivre’u należy dziękowanie za udostępnienia postu i retweety ${ }^{24}$. Ideałem byłoby podziękowanie krótkim postem lub emotikoną każdemu użytkownikowi, ale w przypadku dużej liczby fanów może to być trudne. Warto natomiast przyjąć zasadę dziękowania za wpisy, w których oznaczono fundację. Tym bardziej, jeśli są to posty znanych osób (Krzysztof Ziemiec o Caritas Polska czy Paweł Tkaczyk o fundacji

\footnotetext{
${ }^{18}$ Zob. J. Falls, E. Deckers, Media społecznościowe bez ściemy. Jak kreować markę, Gliwice 2013, s. 133-152.

${ }^{19}$ Screen w posiadaniu Autorki.

${ }^{20}$ Stowarzyszenie Wiosna z okazji 15-lecia Szlachetnej Paczki przygotowało film nt. pracowników fundacji; https://www.youtube.com/watch?v=yVoyW2UlGac, (dostęp: 30.12.2017 r.).

${ }^{21}$ Zob. M. Sadowski, Rewolucja social media, Gliwice 2013, s. 89-105.

${ }^{22}$ FaniMani.pl, Jak prowadzić działania na Twitterze - poradnik dla non profit cz.1, https://fanimani.pl/ blog/jak-prowadzic-dzialania-na-twitterze-poradnik-dla-non-profit-cz-1/, (dostęp: 30.12.2017 r.).

${ }^{23}$ Fundacja Dzieciom „Zdążyć z pomocą” skorzystała z pomocy JDabrowsky, znanego youtubera, który włączył się w jedną z akcji charytatywnych.

${ }^{24}$ FaniMani.pl, Jak prowadzić..., dz. cyt.
} 
Anny Dymnej ${ }^{25}$. Dziękować należy także tym, którzy włączają się w projekty fundacji czy promocję jej działań (dotyczy to także mediów). Można podlinkować artykuł na stronie fundacji oznaczając redakcję przez „@”. Niepisanym zwyczajem w social media jest zasada wzajemności, w ramach której obserwuje się/lubi fanpage/konto osoby, która dołączyła do grona followersów/użytkowników fundacji.

- Skracanie linków jest jedną z fundamentalnych zasad w mediach społecznościowych. Można to zrobić korzystając ze specjalnych serwisów (np. Bitly.com), zaś na Facebooku usunąć je całkowicie pozostawiając okno ze zdjęciem i leadem tekstu odsyłającym bezpośrednio do artykułu ${ }^{26}$.

- Używanie hashtagów jest kolejnym sposobem zwiększenia zasięgu odbiorców. Wpisywanie słów poprzedzonych znakiem „\#” można wykorzystać zarówno na Facebooku, jak i na Twitterze (ułatwia wyszukiwanie treści). Hashtagi służą ponadto skróceniu postów (kilka tagów zamiast pełnych zdań). Najcenniejsze jest tworzenie własnych hashtagów, zwłaszcza w przypadku kampanii społecznych, akcji czy projektów z atrakcyjną nazwą własną ${ }^{27}$. Za przykład może posłużyć akcja Caritas Polska pod hasłem „Tornister pełen uśmiechów”.

- Dobrą praktyką jest nawiązywanie do aktualnych wydarzeń. W social media wszystko dzieje się bardzo szybko, dlatego administratorzy fanpage'a powinni działać na bieżąco. Aktualne wydarzenia można wykorzystać w kontekście zbierania funduszy na rzecz $\mathrm{OPP}^{28}$. Aby być na bieżąco, należy śledzić to, co w danym momencie absorbuje uwagę użytkowników social media. Włączanie się w trwającą na Twitterze dyskusję ułatwia obserwowanie trendów (lewy górny róg).

- Warto zadbać o maksymalne uproszczenie mechanizmu przekazywania datków na fundację, także z wykorzystaniem social media. Nie chodzi tylko o odsyłanie do stron www, gdzie dokonuje się odpisu $1 \%$, ale o tworzenie aplikacji, za pośrednictwem których można dokonać wpłaty ${ }^{29}$.

- W mediach społecznościowych sprawdza się poczucie humoru i dystans ${ }^{30}$. Używanie emotikon nie zmniejsza powagi OPP, a zdecydowanie skraca posty (co szczególnie ważne na Twitterze) ${ }^{31}$. Wpisy z ikonami bardziej angażują użyt-

\footnotetext{
${ }^{25}$ Screen w posiadaniu Autorki.

${ }^{26}$ FaniMani.pl, Jak prowadzić..., dz. cyt.

${ }^{27}$ FaniMani.pl, Jak prowadzić..., dz. cyt.

${ }^{28}$ Z okazji 11 listopada Fundacja Anny Dymnej zachęcała do zakupu rogali świętomarcińskich. Dochód z ich sprzedaży dzięki Charytatywni.Allegro został przekazany na rzecz podopiecznych organizacji.

${ }^{29}$ Nowoczesne rozwiązania w kwestii wpłat na rzecz fundacji, korzystając z social media stosuje np. Caritas Polska oraz Fundacja Anny Dymnej.

${ }^{30}$ J.C. Levinson, S. Gibson, Marketing partyzancki w mediach społecznościowych. 126 narzędzi w walce o pozycję w internecie, Warszawa 2013, s. 58-62.

${ }^{31}$ FaniMani.pl, Jak prowadzić..., dz. cyt.
} 
kowników. Podobnie jest w przypadku żartobliwych postów, zwłaszcza pokazujących dystans do siebie ${ }^{32}$. Można żartować, jednak nie warto publikować wpisów zbyt osobistych, które mogłyby znaleźć się na prywatnym koncie, ale nie oficjalnym fanpage'u.

Aktywność w social media wymaga od fundacja przemyślanej i długofalowej strategii, która składa się na całościową politykę komunikacji medialnej ${ }^{33}$. Warto być obecnym w różnych kanałach społecznościowych, gdyż zwiększa to szanse na dotarcie do nowych odbiorców. Konta w kanałach społecznościowych powinny być zsynchronizowane ${ }^{34}$, ale raczej należy unikać multiplikowania treści. Może to świadczyć o braku kreatywności administratorów, a odbiorców nudzić. Profilu na Twitterze nie należy łączyć z Facebookiem tak, by na tablicy automatycznie pojawiały się adnotacje o nowych aktualizacjach. Można natomiast korzystać z wtyczek na stronie www, które ułatwią szybkie polecenie tekstu w mediach społecznościowych oraz z aplikacji Click to tweet, aby bezpośrednio zamieszczać na Twitterze cytaty z wpisów na blogu czy stronie $w w w^{35}$.

\section{Wnioski, propozycje}

Media społecznościowe są ważnym elementem polityki medialnej organizacji non profit. Aktywność w social media jest stosunkowo tanim (w porównaniu z wykupieniem reklamy w tradycyjnych mediach), a więc łatwo dostępnym dla niewielkiej organizacji ${ }^{36}$, sposobem budowania szerokiego zasięgu. Za pośrednictwem serwisów społecznościowych można wzmacniać przekaz generowany w tradycyjnych kanałach.

Aby komunikacja w mediach społecznościowych przekładała się na zwiększanie skuteczności OPP, powinna spełniać kilkanaście warunków, które w skrócie można opisać jako umiejętne, rozsądne i przemyślane korzystanie z narzędzi poszczególnych serwisów.

Podsumowując, warto zaproponować, aby administracją kanałów społecznościowych fundacji zajmowała się osoba (grupa osób) dedykowana wyłącznie temu zadaniu. Aktualizowanie kont w social media to praca $7 \mathrm{dni}$ w tygodniu, 24 godziny na dobę - Facebooka nie da się wyłączyć o godz. 16 i wyjść z biura. Niestety, jak pokazują badania, w wielu firmach nadal powszechną praktyką jest zlecanie administracji kont społecznościowych w ramach dodatkowych obowiązków pracowników ${ }^{37}$, co oznacza

\footnotetext{
${ }^{32}$ Szlachetna Paczka zamieszcza np. grafikę z popularną postacią z filmu Star Wars, który nosi logi fundacji albo żarty (poprzedzając je \#suchartime); screeny w posiadaniu Autorki.

${ }^{33}$ Zob. A. Miotk, Skuteczne social media, Gliwice 2013, s. 62-70.

${ }^{34}$ Zob. A. Podlaski, Marketing społecznościowy. Tajniki skutecznej promocji w social media, Gliwice 2011, s. 81-82.

${ }^{35}$ FaniMani.pl, Jak prowadzić działania na Twitterze - poradnik dla non profit cz.3, https://fanimani.pl/blog/jak-prowadzic-dzialania-na-twitterze-poradnik-dla-non-profit-cz-3/, (dostęp: 30.12.2017 r.).

${ }^{36}$ Zob. J. Lipski, Marketing małej firmy w mediach społecznościowych - jak podejść do niego strategicznie, w: „Marketer+” 4/2017, s. 30-33.

${ }^{37}$ Deloitte, Biznes społecznościowy - nowa era w komunikacji biznesowej. Raport na podstawie badania
} 


\section{PUBLIC RELATIONS W INSTYTUCJACH NON-PROFIT}

brak jednoznacznej odpowiedzialności za dodawane treści ${ }^{38}$. Ważne jest ponadto dokonywanie systematycznych pomiarów i optymalizowanie komunikacji, by osiągać lepsze efekty ${ }^{39}$. Korzystanie z pomocy profesjonalistów w dziedzinie komunikacji w social media jest szansą na zwiększenie skuteczności organizacji ${ }^{40}$.

\section{BIBLIOGRAFIA:}

Axelrod S., Stop Reading About Social Media Trends And Start Listening, http://techcrunch.com/2015/12/22/stop-reading-about-social-mediatrends-and-start-listening/.

Brzezińska-Waleszczyk M., Dobre praktyki praktyki w komunikacji marek w mediach społecznościowych, „Studia Medioznawcze” 4/2015, s. 67-78.

Caritas Polska, Komunikat Caritas Polska w sprawie działań na rzecz uchodźców, http://www.caritas.pl/komunikat-caritas-polska-w-sprawie-dzialanna-rzecz-uchodzcow/.

Deloitte, Biznes społecznościowy - nowa era w komunikacji biznesowej. Raport na podstawie badania „Polskie firmy na Facebooku - portale społecznościowe w komunikacji marketingowej polskich przedsiębiorstw", https://marketingowe.files.wordpress.com/2013/10/raport-biznes-spolecznosciowy.pdf.

Dębski Ł., Statystki Facebooka w Polsce. Stan na 08.2016, http://www.infosocialmedia.pl/statystyki-facebooka-w-polsce-2q-2016/.

Falls J., Deckers E., Media społecznościowe bez ściemy. Jak kreować markę, Gliwice 2013.

FaniMani.pl, Jak prowadzić działania na Twitterze - poradnik dla non profit $c z .2$, https://fanimani.pl/blog/jak-prowadzic-dzialania-na-twitterze-poradnik-dla-non-profit-cz-2/.

FaniMani.pl, Jak prowadzić działania na Twitterze - poradnik dla non profit cz.1, https://fanimani.pl/blog/jak-prowadzic-dzialania-na-twitterze-poradnik-dla-non-profit-cz-1/.

FaniMani.pl, Jak prowadzić działania na Twitterze - poradnik dla non profit $c z .3$, https://fanimani.pl/blog/jak-prowadzic-dzialania-na-twitterze-poradnik-dla-non-profit-cz-3/.

Gitomer J., Społecznościowy boom! Wykorzystaj potencjał sieci e-kontaktów do wykreowania marki, zwiększenia sprzedaży i zdominowania rynku, Gliwice 2012.

\footnotetext{
„Polskie firmy na Facebooku - portale społecznościowe $w$ komunikacji marketingowej polskich przedsiębiorstw”, https://marketingowe.files.wordpress.com/2013/10/raport-biznes-spolecznosciowy.pdf, (dostęp: 30.12.2017 r.).

${ }^{38}$ Zob. M. Brzezińska-Waleszczyk, Dobre praktyki praktyki w komunikacji marek w mediach społecznościowych, w: Studia Medioznawcze 4/2015, s. 69-70.

${ }^{39}$ Zob. J. Lovett, Sekrety pomiarów w mediach społecznościowych, Gliwice 2012, s. 231-262.

${ }^{40}$ Zob. A. Miotk, Nowy PR. Jak internet zmienił public relations, Lublin 2016, s. $238-265$.
} 
Gustowski W., Komunikacja w mediach społecznościowych, Gdynia 2012.

Gwóźdź M., Liczby polskiego internetu 2015, http://smmeasure.eu/liczby-polskiego-internetu-2015/.

Gwóźdź M., Liczby polskiego internetu 2016, http://zblogowani.pl/wpis/2023462/liczby-polskiego-internetu-2016.

Levinson J.C., Gibson S., Marketing partyzancki w mediach społecznościowych. 126 narzędzi $w$ walce o pozycję w internecie, Warszawa 2013.

LK/Warszawa/KAI, 44 proc. Polaków wsparło organizacje pożytku publicznego, http://www.niedziela.pl/artykul/6526/44-proc-Polakow-wsparlo-organizacje.

Lovett J., Sekrety pomiarów w mediach społecznościowych, Gliwice 2012.

Marchwicki M., Szlachetna Paczka bije rekordy na Facebooku, http://socialpress.pl/2014/12/szlachetna-paczka-bije-rekordy-na-facebooku/.

Ministerstwo Finansów, Informacja dotycząca kwot 1\% należnego podatku dochodowego od osób fizycznych przekazanych organizacjom pożytku publicznego z rozliczenia za 2013 rok, http://www.finanse.mf.gov.pl/documents/766655/2970107/Wykaz+organizacji+po\%C5\%BCytku+publicznego $\% 2 \mathrm{C}+\mathrm{kt} \% \mathrm{C} 3 \% \mathrm{~B} 3 \mathrm{re}+\mathrm{w}+2014+\mathrm{r}$.+otrzyma\% $\% 5 \% 82 \mathrm{y}+1+$ proc.

Ministerstwo Finansów, Informacja dotycząca kwot 1\% należnego podatku dochodowego od osób fizycznych przekazanych organizacjom pożytku publicznego z rozliczenia za 2014 rok, http://www.finanse.mf.gov.pl/documents/766655/5008832/Wykaz+organizacji+po\%C5\%BCytku+publicznego $\% 2 \mathrm{C}+\mathrm{kt} \% \mathrm{C} 3 \% \mathrm{~B} 3 \mathrm{re}+\mathrm{w}+2015+$ otrzyma\% $\mathrm{C} 5 \% 82 \mathrm{y}+\mathrm{kwoty}+1+$ proc.

Miotk A., Nowy PR. Jak internet zmienił public relations, Lublin 2016, s. 238265

Miotk A., Skuteczne social media, Gliwice 2013.

Pełechaty M., Społeczności internetowe, w: Pankiewicz K. (red.), E-marketing w akcji, Gliwice 2008, s. 151-165.

Podlaski A., Marketing społecznościowy. Tajniki skutecznej promocji w social media, Gliwice 2011.

Sadowski M., Rewolucja social media, Gliwice 2013.

\section{O AUTORCE:}

Mgr lic. Marta Brzezińska-Waleszczyk, Przygotowuje rozprawę doktorską o nowej ewangelizacji w social media (planowana obrona - styczeń 2018). Dziennikarka i publicystka. Wspólpracowała m.in. z Rzeczpospolitą, Deon.pl, Przewodnikiem Katolickim, Natemat.pl oraz Wirtualną Polską. Obecnie szef działu Kultura w polskiej edycji międzynarodowego serwisu Aleteia. Kontakt: mart.bre@gmail.com 